\title{
22. PALEOCENE FORAMINIFERA FROM DSDP SITE 283, SOUTH TASMAN BASIN
}

\author{
Peter N. Webb, New Zealand Geological Survey, Department of Scientific \\ and Industrial Research, Lower Hutt, New Zealand'
}

\section{INTRODUCTION}

Thirty-six species of agglutinated Paleocene foraminifera were recovered from eight cores of the lowermost 400 meters of sediments encountered at Site 283, South Tasman Basin (Figure 1). Site 283 is located at lat. $43^{\circ} 54.60^{\prime} \mathrm{S}$ and long. $154^{\circ} 16.96^{\prime} \mathrm{E}$ and the stratigraphic interval investigated lies between 4948 and 5309 meters below sea level. Lithologies from Cores 9 and 11 consist of mottled greenish-gray and brownishgray silty clay (Unit 3 ) whereas lithologies from Cores 12 to 17 (Unit 4), consist of an olive black pyritic silty clay and silty claystone (Table 1). An arbitrary lithological boundary of Units 3 and 4 was established between Cores 11 and 12 . The sedimentary sequence cored overlies an altered pillow lava, or pillow breccia.

\section{FORAMINIFERA}

Thirty-six species of foraminifera were recovered from the 37 10-cc samples investigated. Most samples are characterized by a high abundance of tests and very low species diversity. Greatest diversity of 21 species was encountered in the lowermost samples (i.e., $17-5,38 \mathrm{~cm}$ and 17, CC) (Table 1). Lower diversities are apparent in the upper part of Unit 4 and the overlying Unit 3.

Dominant taxa in Units 4 and 3 are Bathysiphon cylindrica (Glaessner), Ammodiscus cretaceus (Reuss), Glomospira charoides (Parker and Jones), Kalamopsis grzybowskii (Dylazanka), Lituotuba lituiformis (Brady), Rzehakina epigona (Rzehak), Recurvoides deflexiformis (Noth), and Bolivinopsis spectabilis (Grzybowski). Stratigraphically important taxa such as Gaudryina whangaia (Finlay) and Conotrochammina whangaia

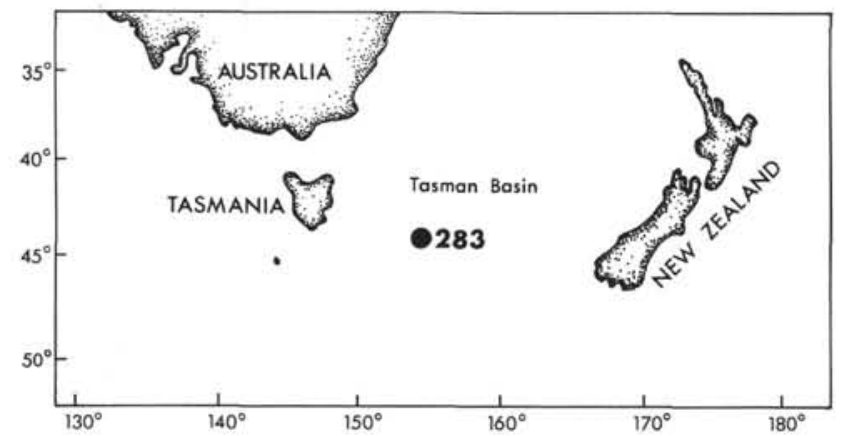

Figure 1. Map of Tasman Sea showing location of Site 283.

\footnotetext{
'Presently Chairman, Department of Geology Northern Illinois University, DeKalb, Iflinois.
}

Finlay are extremely rare. Preservation is particularly good with only a small proportion of the tests deformed. In most instances the chambers are empty, but a few cases of pyrite in-filling were noted. There is no trace of calcareous taxa or the internal casts of calcareous taxa. There appears to be no downhole contamination in this interval at this site.

\section{SYSTEMATIC PALEONTOLOGY \\ Rhabdammina cf. linearis (Brady) (Plate 1, Figure 1)}

Rare in seven of the samples investigated. The test wall material is siliceous with a smooth, shiny, exterior finish, therefore differing from Brady's coarser-grained Recent specimens. Rhabdammina annulata (Grzybowski) from the Eocene-Oligocene of the Polish Carpathians is superficially similar, but it is possible that Grzybowski's material represents the uniserial portion of Lituotuba, or some similar genus. The material from Site 283 consists only of the swollen chamber, and two (broken) radiating arms.

TABLE 1

Distribution of Foraminifera Recovered From Cores 9 to 17 at Site $\mathbf{2 8 3}$

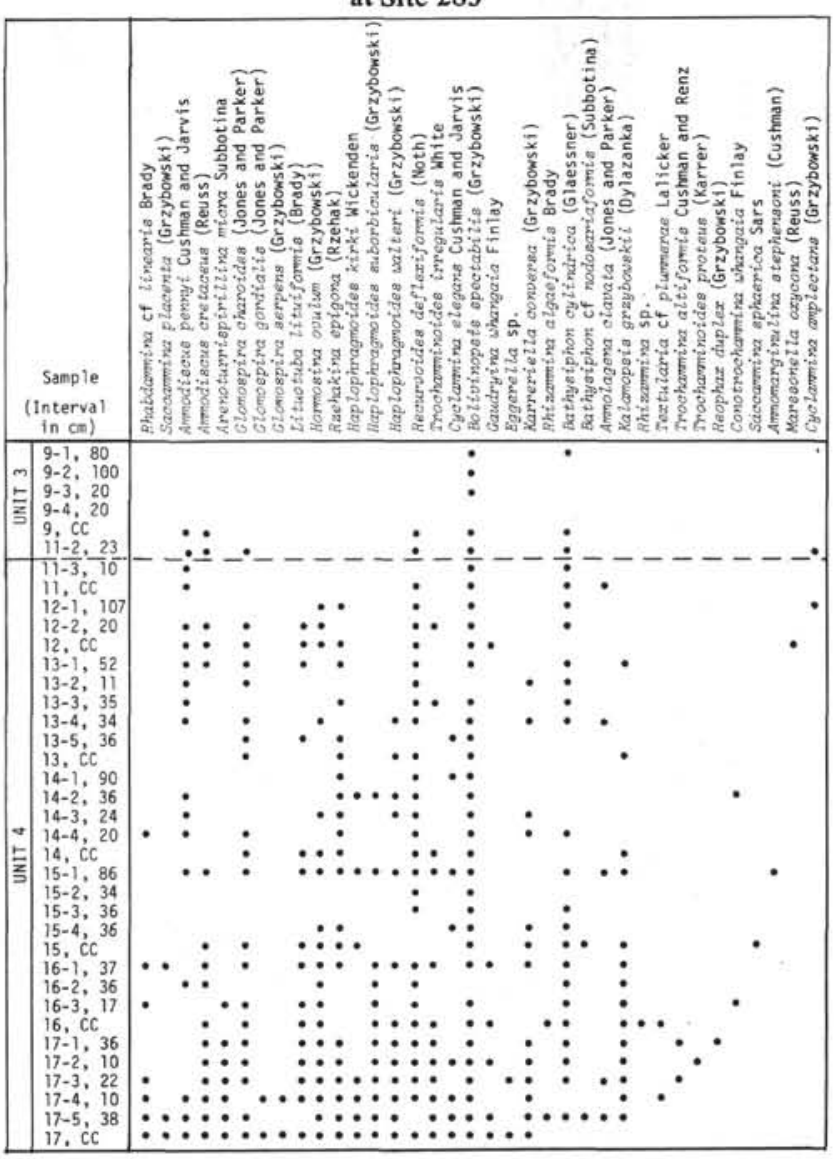


Rhizammina algaeformis (Brady)

(Plate 1, Figure 2)

A small sinuous tube, open at both ends, and not displaying a branching habit. Test wąll constructed of finely agglutinated sand and silt. Present only in Samples 16, CC and 17-5, $38 \mathrm{~cm}$.

\section{Rhizammina sp. \\ (Plate 1, Figure 3)}

A single specimen occurs in Sample 16, CC. The test is a simple nonseptate tube but with minor dislocations along its length. It has a test wall of very fine agglutinated silica and clay.

\section{Bathysiphon cylindrica (Glaessner)}

(Plate 1, Figure 4)

The most common of the simple monothalamous taxa present at Site 283. The test consists of a simple tube with slight constrictions in places. The test wall is composed of quartz grains up to $0.1 \mathrm{~mm}$ diameter.

\section{Bathysiphon ef. nodosariaformis (Subbotina)} (Plate 1, Figure 5)

Single specimens occur in Samples 15, CC, 17-5, $38 \mathrm{~cm}$ and are tentatively referred to this taxon. The Site 283 material shows greatest similarity to Bathysiphon nodosariaformis (Subbotina) from the Late Cretaceous of Moravia (Hanzlikova, 1972: p. 31, pl. 1, fig. 10, 11; pl. 2, fig. 102). The robust test is constructed of finely agglutinated quartz and is characterized by numerous transverse constrictions. There is a superficial similarity to Thomasinella, but the branching habit of that genus is not apparent here.

\section{Saccammina placenta (Grzybowski)}

(Plate 1, Figure 6)

Rare, restricted to one or two specimens in each of three samples The test is a simple flask-shaped chamber with the aperture produced on a neck. In some instances the neck may be broken away at its base. The test wall consists of extremely fine silica giving a smooth and shiny exterior.

\section{Saccammina sphaerica Sars}

(Plate 1, Figure 7)

A single specimen was recovered from Sample Core 15, CC. The test composed of finely agglutinated quartz. It is finer-grained than New Zealand Late Cretaceous (Haumurian) and Paleocene (Teurian) specimens.

\section{Ammodiscus pennyi Cushman and Jarvis (Plate 1, Figure 8)}

This species is moderately common. The test is smaller and composed of finer agglutinated material than New Zealand specimens.

\section{Ammodiscus cretaceus (Reuss)}

(Plate 1, Figure 9)

A common species in the lower part of the succession at Site 283. The test is always smaller than Ammodiscus pennyi. It also resembles A. glabratus (Cushman and Jarvis) from the Lizard Springs Marl of Trinidad.

\section{Arenoturrispirillina micra (Subbotina)} (Plate 1, Figures 10, 11)

This is quite common in the lower part of the succession (i.e., between Samples 16-3,17 cm, and 17, CC. The test consists of three or four whorls of a simple, undivided agglutinated tube arranged in a conical fashion. This material closely resembles Subbotina's species from the upper Eocene of the northern Caucasus. This taxon has not been reported so far from the New Zealand Paleocene and Eocene.

\section{Glomospira charoides (Jones and Parker)}

(Plate 1, Figure 12)

Common throughout most of the succession.
Glomospira gordialis (Jones and Parker)

(Plate 1, Figures 13, 14)

Rare.

Glomospira serpens (Grzybowski)

(Plate 1, Figure 15)

This species is confined to the lower part of the succession (Core 17).

\section{Ammolagena clavata (Jones and Parker)}

(Plate 1, Figure 16)

Rare, found attached mostly to Ammodiscus pennyi and Lituotuba lituiformis.

\section{Lituotuba lituiformis (Brady)}

(Plate 1, Figure 17)

Common throughout the succession. Only one intact specimen was found. More commonly, the irregularly coiled initial chambers and uniserial rectilinear chambers are separated. It seems probable that each portion has been given separate names by earlier workers. For instance, it seems almost certain that such taxa as Trochamminoides acervulatus (Grzybowski) are nothing more than the initial portion of Lituotuba. The rectilinear uniserial chambers have been referred to various species of Reophax and Nodellum.

\section{Kalamopsis gryzbowskii (Dylazanka)}

(Plate 1, Figures 18, 19)

This species is distributed through much of the succession, being particularly common between $15, \mathrm{CC}$ and $17, \mathrm{CC}$. Occurs as undivided tubes and tubes subdivided by septa. A conspicuous constriction marks the location of the septa. Many of the tests are flattened. Siliceous with a shiny external finish.

\section{Hormosina ovulum (Grzybowski) \\ (Plate 2, Figures 1, 2)}

Common through most of the succession but better represented between Samples 15-4, $36 \mathrm{~cm}$ and 17, CC. Small, shiny, opaque, siliceous tests.

\section{Reophax duplex (Grzybowski)}

(Plate 2, Figure 3)

A single specimen was recovered from Sample $17-1,36 \mathrm{~cm}$. It is unclear whether one or more chambers have been broken away. If this had occurred there would be a likeness to Reophax pilulifer (Brady) and Hormosina trinitatensis (Cushman and Renz).

\section{Rzehakina epigona (Rzehak)}

(Plate 2, Figures 4, 5)

Abundant through most of the succession. In Samples 12, CC and $14, \mathrm{CC}$, there are a few tests in which the early coiling plane differs from that of the later whorls. Scott (1961) placed such tests in his "gamma group" of Rzehakina epigona and noted that this group was present in the Paleocene (Teurian) sediments of southern Hawke's Bay and Raukumara Peninsula, New Zealand.

\section{Haplophragmoides kirki (Wickenden)}

(Plate 2, Figures 6, 7)

Smallest of the three species of Haplophragmoides recognized here. Common in Core 17, and occurring only sporadically above this level. Tests very small $(0.30 \mathrm{~mm}$ axial diameter $)$. With a fine-grained siliceous test wall, and five chambers in the final whorl. Reported from the Late Cretaceous (Haumurian) of New Zealand (Webb, 1971) and Late Cretaceous-Paleocene of Trinidad (Beckmann 1960).

\section{Haplophragmoides suborbicularis (Grzybowski)}

(Plate 2, Figures 8, 9)

Common in Cores 16 and 17 , but occurring only sporadically above this level. Characterized by a highly inflated subspherical test outline with very wide final chambers. Test wall finely siliceous. Quite common in the New Zealand Late Cretaceous (Haumurian) (Webb, 1971). 


\section{Haplophragmoides walteri (Grzybowski)}

(Plate 2, Figures 10, 11)

Common in Cores 16 and 17 , and occurring only sporadically above this level. Test finely siliceous and translucent. Walls compressed, periphery subacute. Externally similar to Cyclammina amplectans (Grzybowski).

\section{Recurvoides deflexiformis (Noth)}

(Plate 2, Figure 12)

Common throughout the succession.

\section{Trochamminoides irregularis (White)}

(Plate 2, Figure 13)

As noted above, it is debatable whether this form should be regarded as a distinct taxon because it is possibly the initial portion of Lituotuba lithiformis (Brady).

\section{Trochamminoides proteus (Karrer) (Plate 2, Figure 14)}

Rare. This material also shows some resemblance to Trochamminoides elegans (Grzybowski).

\section{Cyclammina elegans Cushman and Jarvis}

(Plate 2, Figures 15, 16)

A few specimens are distributed through 8 of the 37 samples. The uppermost occurrence is in Sample 13-5, $36 \mathrm{~cm}$. Recognition of the alveolar chamber walls is difficult or impossible in some instances, and a few specimens might be more correctly referred to Haplophragmoides glabra (Cushman and Waters). Common in New Zealand Late Cretaceous and Paleocene (Haumurian-Teurian) (Webb, 1971). Test wall components in Site 283 material are much finer than those encountered in New Zealand specimens.

\section{Cyclammina amplectans (Grzybowski)}

Single specimens in Samples 11-2, $23 \mathrm{~cm}$, and 12-1, $107 \mathrm{~cm}$, are referred to this taxon. Both are small compressed siliceous tests with the simple secondary chamber extension in the walls. In New Zealand this taxon (known originally as Cyclammina grangei [Finlay], but revised by Webb(1970) as C. amplectans [Grzybowski]) ranges between the Waipawan and Bortonian Stages (latest Paleocene to mid Eocene), with a few occurrences in the Teurian Stage (Paleocene).

\section{Ammomarginulina stephensoni (Cushman)}

(Plate 2, Figure 17)

A single specimen was recovered from Sample $15-1,86 \mathrm{~cm}$. Very common in the much shallower facies of the New Zealand Late Cretaceous, and Paleocene (Haumurian-Teurian) (Webb, 1971, 1973a).

Bolivinopsis spectabilis (Grzybowski)

(Plate 3, Figures 1-3)

Abundant throughout the succession. This is a particularly difficult taxon to subdivide and it is recognized that there are almost certainly two species present and possibly more. For the moment they are grouped under a single name. The greater proportion can safely be referred to $B$. spectabilis. In several samples there are tests which resemble $B$. compta (Finlay), a species characterized by a smaller test than $B$. spectabilis, and a megalospheric test in which the whorl is about the same width as the succeeding biserial chambers. The test maintains a uniform width from initial to terminal ends. In New Zealand $B$. compta ranges through the Paleocene and mid Eocene (Teurian-Bortonian).

\section{Textularia cf. plummerae (Lalicker)} (Plate 3, Figure 4)

A common member of Late Cretaceous-Paleocene assemblages in New Zealand.

\section{Conotrochammina whangaia (Finlay)}

(Plate 3, Figures 5, 6)

Rare single specimens in Samples 14-2, $36 \mathrm{~cm}$, and $16-3,17 \mathrm{~cm}$. A particularly diagnostic species for the Teurian Stage (Paleocene) in New Zealand. This is the second reported occurrence of this species outside the New Zealand land area. Webb (1973b) reported a single specimen in Teurian sediments at Site 208 on the Lord Howe Rise. It is much more abundant in the shallower water, more inshore facies, now outcropping along the east coast of New Zealand. Test wall components are always coarse grained.

\section{Trochammina altiformis (Cushman and Renz)}

(Plate 3, Figures 7-9)

Rare, present as single specimens in Samples 17-1, $36 \mathrm{~cm}$ and 17-3, $22 \mathrm{~cm}$. The specimens available seem identical to Cushman and Renz's Lizard Springs Formation species.

\section{Gaudryina whangaia (Finlay)}

(Plate 3, Figure 10)

Present as a few specimens in six samples. More common in Core 17 , but with a single occurrence as high as Sample 12, CC. The illustrated specimen has a length of $0.6 \mathrm{~mm}$, which is rather smaller than its counterpart in New Zealand. A common member of New Zealand Paleocene assemblages, and a diagnostic species for the Teurian Stage. The triserial portion makes up about one-third of the length of the test, while the biserial portion consists of three or four chambers usually twisted about the long axis. Wall components of the Site 283 specimens are finer than their New Zealand counterparts. Webb (1973b) reported Gaudryina whangaia from the Teurian (Paleocene) of Site 208, Lord Howe Rise.

\section{Eggerella sp.}

(Plate 3, Figure 11)

Rare, single specimens in Samples 17-3, $22 \mathrm{~cm}$, and 17, CC. The available specimens were compared with the New Zealand Teurian index Eggerella columna (Finlay) and it is possible that the Site 283 material represents an early ontogenetic stage of this species.

\section{Karreriella conversa (Grzybowski) \\ (Plate 3, Figure 12)}

Quite common in 13 of the samples. Not present above Sample 13-2, $11 \mathrm{~cm}$. Carpathian workers have generally referred this species to Plectina, a genus defined as having a rounded areal aperture with a small valvular tooth. This structure has not been recognized in the present material and the genus Karreriella is preferred.

\section{Marsonella oxycona (Reuss)}

(Plate 3, Figure 13)

A single large specimen occurs in Sample 12, CC.

\section{AGE AND CORRELATION}

No refined biostratigraphic subdivision of this succession can be attempted on foraminifera. Most taxa are long-ranging, i.e., Late Cretaceous to Oligocene. On the available foraminiferal evidence the interval from Sample 12-2, $20 \mathrm{~cm}$ to Sample 17, CC is Paleocene, and can be correlated with the New Zealand Teurian Stage. The interval from Sample 9, CC to Sample 12-1, $107 \mathrm{~cm}$, is probably late Paleocene to Eocene. This two-fold foraminiferal subdivision coincides approximately with the lithologic subdivision established for the site.

The Teurian (Paleocene) age for Unit 4 is based on the occurrence of Gaudryina whangaia in Samples 12, CC to 17, CC (Table 1), and Conotrochammina whangaia (Finlay) in Samples 14-2, $36 \mathrm{~cm}$, and 16-3, $17 \mathrm{~cm}$. As 
noted above, "gamma" variants (Scott, 1961) of Rzehakina epigona (Rzehak) are present, and support the Paleocene age proposed here. Bolivinopsis compta (Finlay) appears to be present in small numbers among the $B$. spectabilis (Grzybowski) group. The former species appears in the Teurian and ranges up into the Bortonian (Eocene).

Only a very approximate indication of the age of Unit 3 is provided by foraminifera. The marked drop in species diversity, when compared with the underlying Unit 4 faunas, is striking, and can be interpreted as indicating a radical change in bottom conditions, and probably the presence of a hiatus in this part of the column. The Teurian (early-middle Paleocene) indicators mentioned above do not pass up into Unit 3, and this negative evidence might be interpreted as indicating a post-Teurian (late Paleocene or younger) age for these sediments. Cyclammina amplectans is the only useful taxon present. This species occurs most commonly in the Waipawan to Bortonian (late Paleocene to middle Eocene) in New Zealand with only a few recorded in the Teurian.

\section{PALEOECOLOGY}

The recovery of moderately good Paleocene faunas 5000 meters below present sea level is of considerable ecological interest. Remarkably similar Recent assemblages are known from the Kuru-Kamchatka Trench and adjoining abyssal plain (Saidova, 1961a) and in the northeast Pacific at depths between 3500 and 6500 meters (Saidova, 1961 b), and depths down to 6250 meters in the Peru-Chile Trench (Bandy and Rodolfo, 1964). Comparable fossil faunas, mostly Late Cretaceous to Oligocene in age have been studied in considerable detail in southern Poland (Grzybowski, 1897, 1901; Dylazanka, 1923; Geroch, 1960), Austria (Grün, 1969), and Trinidad (Cushman and Jarvis, 1928; Cushman and Renz, 1946; Beckmann, 1960). In the southwest Pacific descriptions of fossil siliceous and agglutinated faunas have been provided by Finlay (1939) Waitangi-Paleocene; Scott (1961); Brouwer (1965) Waitangi-Paleocene; and Webb (1971) Eastern Basin-Late Cretaceous in New Zealand; and Keij (1964) in Borneo. Brouwer (1965) reviewed the literature on Recent and fossil occurrences of siliceous and agglutinated microfaunas, and referred to them as "Rhabdammina" faunas. Brouwer concluded that an abyssal environment was the most likely for these assemblages. The occurrence of a Paleocene-Eocene "Rhabdammina" fauna at a present depth of 5000 meters in the South Tasman Basin (Site 283) supports this view. It is concluded, that during the Paleocene-early Eocene, sedimentation at Site 283 proceeded in an abyssal environment well below the CCD.

\section{ACKNOWLEDGMENTS}

Material illustrated on Plates 1 to 3 is filed in the New Zealand Geological Survey collection of figured specimens (FP2480 to FP2520). I would like to thank Dr. D. G. Jenkins for providing me with this material, and Mr. R. C. Brazier, New Zealand Geological Survey for preparing illustrations of foraminifera. Dr. Hornibrook and Messrs. Edwards and Wilson criticized early drafts of this paper.

\section{REFERENCES}

Bandy, O. L. and Rodolfo, K. S., 1964. Distribution of foraminifera and sediments, Peru-Chile Trench area: DeepSea Res., v. 11, p. 817-837.

Beckmann, H. P., 1960. Distribution of benthonic foraminifera at the Cretaceous-Tertiary boundary of Trinidad (West Indies). In The Cretaceous-Tertiary Boundary: Part 5, Internatl. Geol. Congr., 21, Norden, p. 57-69.

Brouwer, J., 1965. Agglutinated foraminiferal faunas from some turbiditic sequences: Koninkl. Nederlander Akad. Wetensch., Proc., Ser. B, v. 68, p. 309-334.

Cushman, J. A. and Jarvis, P. W., 1928. Cretaceous foraminifera from Trinidad: Cushman Lab. Foram. Res. Contrib., v. 4, p. 85-103.

Cushman, J. A. and Renz, H. A., 1946. The foraminiferal fauna of the Lizard Springs Formation of Trinidad: from the Cushman Lab. Foram. Res. Contrib. Spec. Publ. 14.

Dylazanka, M., 1923. Inoceramus beds of the quarry at Szymbark near Gorlice: Rocznik Polskiego Towarzystwa Geologicznego 1: p. 36-80.

Finlay, H. J., 1939. New Zealand Foraminifera: The occurrence of Rzehakina, Hantkenina, Rotaliatina and Zeauvigerina. Roy. Soc. New Zealand Trans., v. 68, p. 534543.

Geroch, S., 1960. Microfaunal assemblages from the Cretaceous and Palaeogene Silesian Unit in the Beskid Slaski Mountains. Inst. Geol. Biul. 153.

Grün, W, 1969. Flysch Microfauna of the Hagenbach Valley (Northern Vienna Woods), Austria: Rocznik Polskiego Torwarzystwa Geologicznego 39: p. 305-334.

Grzybowski, J., 1897. Foraminifera of oil-bearing strata in the neighbourhood of Krosno (translation): Rozpr, Wydz, mat-przyr, pol. Akad, Umiejet, v. 33, p. 257-305.

, 1901. Foraminifera of the Inoceramian Beds in the neighbourhood of Gorlice: Rozpr, Wydz, mat-przyr pol. Adak, Umiejet, v. 41, p. 219-288.

Hanzlikova, E., 1972. Carpathian Upper Cretaceous foraminiferida of Moravia (Turonian-Maestrichtian): Rozpravy Ustrednihio Ustavu Geologickeho, Svazek 39.

Keij, A. J., 1964. Late Cretaceous and Paleogene arenaceous foraminifera from flysch deposits in North Western Borneo: Malaysia Geol. Surv. (Borneo Region), Ann. Rept., p. 155-158.

Saidova, H. M., 1961a. Ekologia i Paleogeografija Dal'nevostochnykh morej SSSR i Severo-Zapadnoj Chasti Tikhogo Okeana: Akad. Nauk SSSR, Inst. Okean.

1961b. Quantitative distribution of bottom foraminifera of northeastern Pacific: Akad. Nauk SSSR, Trudi Inst. Okean. v. 45.

Scott, G. H., 1961. Contribution to the knowledge of Rzehakina Cushman (foraminifera) in New Zealand: New Zealand J. Geol. Geophys. v. 4, p. 3-43.

Webb, P. N., 1970. A preliminary statement on type material of New Zealand upper Cretaceous, Paleocene, and Eocene foraminifera described by H. J. Finlay: New Zealand J. Geol. Geophys. v. 13, p. 663-675.

1971. New Zealand Late Cretaceous (Haumurian) foraminifera and stratigraphy: New Zealand J. Geol. Geophys., v. 14 , p. $795-828$.

1973a. Paleocene foraminifera from Wangaloa and Dunedin: New Zealand J. Geol. Geophys., v. 16, p. 109157.

1973b. Preliminary comments on MaestrichtianPaleocene foraminifera from Lord Howe Rise, Tasman Sea. In Fraser, R., (compiler), Oceanography of the South Pacific: (UNESCO), Wellington, p. 114-146. 



\section{PLATE 1}

(All specimens from Site 283)

Figure 1 Rhabdammina cf. linearis (Brady) Sample 17, CC: $\times 60$.

Figure 2 Rhizammina algaeformis (Brady) Sample 17-5, $38 \mathrm{~cm}: \times 60$.

Figure $3 \quad$ Rhizammina sp.

Sample 16, CC: $\times 30$.

Figure $4 \quad$ Bathysiphon cylindrica (Glaessner) Sample 15, CC: $\times 30$.

Figure 5 Bathysiphon cf. nodosariaformis (Subbotina) Sample 15, CC: $\times 45$.

Figure 6 Saccammina placenta (Grzybowski) Sample 17, CC: $\times 60$.

Figure $7 \quad$ Saccammina sphaerica (Sars) Sample 15, CC: $\times 60$.

Figure 8 Ammodiscus pennyi (Cushman and Jarvis) Sample 12, CC: $\times 60$.

Figure 9 Ammodiscus cretaceus (Reuss) Sample 17, CC: $\times 60$.

Figures 10, 11 Arenoturrispirillina micra (Subbotina) Sample 17, CC: $\times 60$.

Figure 12 Glomospira charoides (Jones and Parker) Sample 17, CC: $\times 80$.

Figure 13 Glomospira gordialis (Jones and Parker) Sample 17, CC: $\times 60$.

Figure 14 Glomospira gordialis (Jones and Parker) Sample 14, CC: $\times 80$.

Figure 15 Glomospira serpens (Grzybowski) Sample 16, CC: $\times 40$.

Figure 16 Ammolagena clavata (Jones and Parker) Sample 11, CC: $\times 40$.

Figure 17 Lituotuba lituiformis (Brady) Sample 15, CC: $\times 60$.

Note: attached to Ammologena clavata (Jones and Parker), as above.

Figure 18 Kalamopsis grzybowskii (Dylazanka) Sample 17-1, $36 \mathrm{~cm}: \times 60$.

Figure 19 Kalamopsis grzybowskii (Dylazanka) Sample 16, CC: $\times 60$. 
PLATE 1
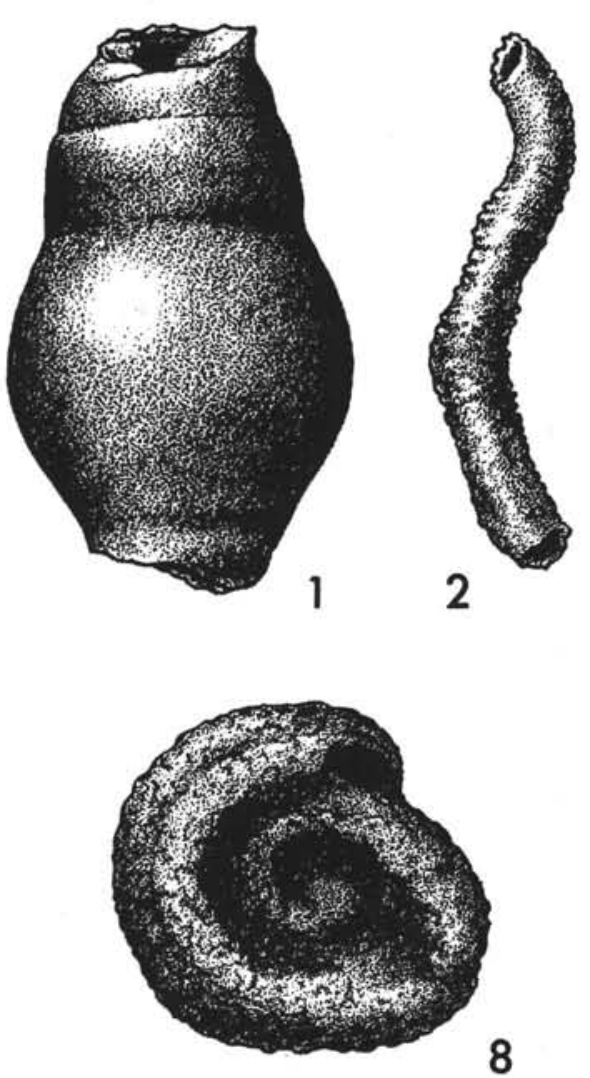

8

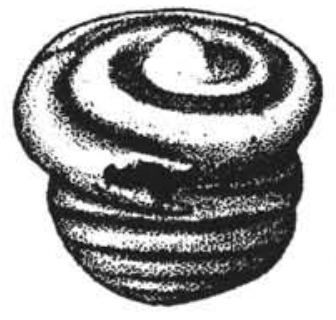

12
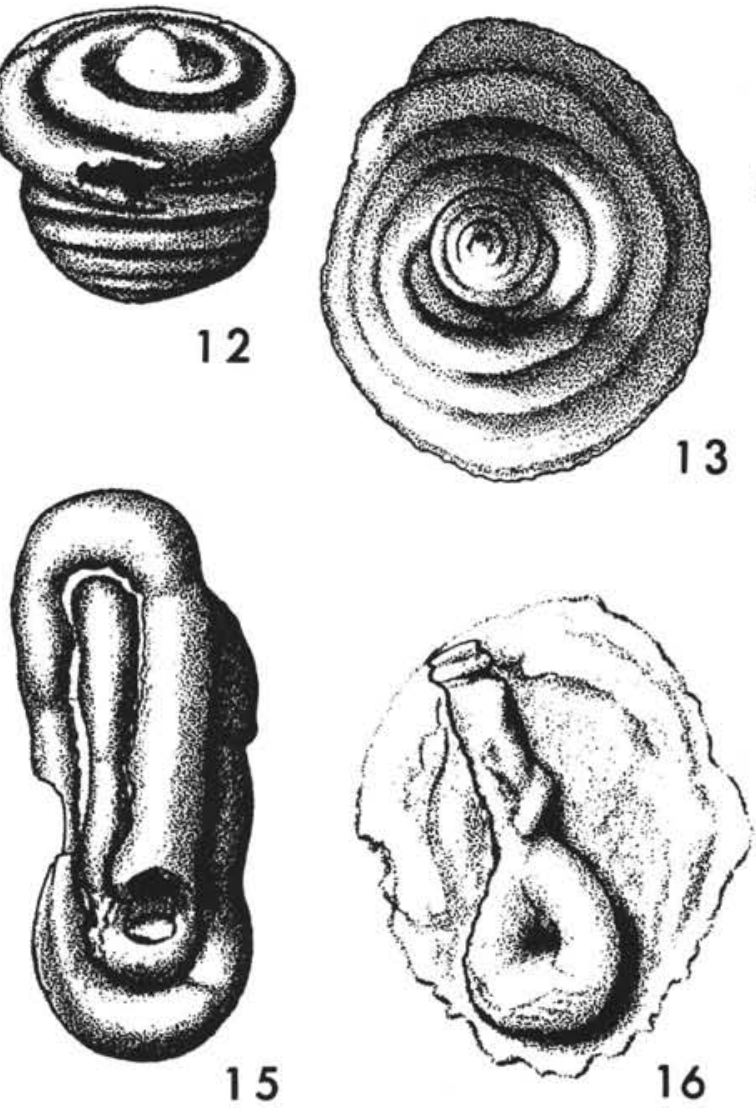

3

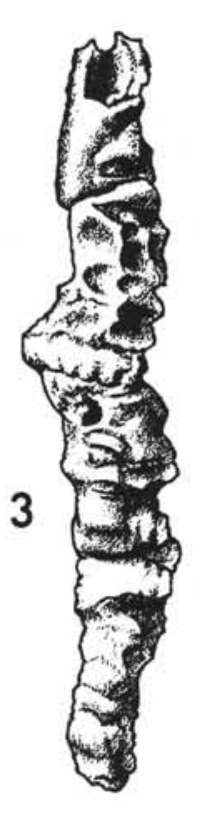

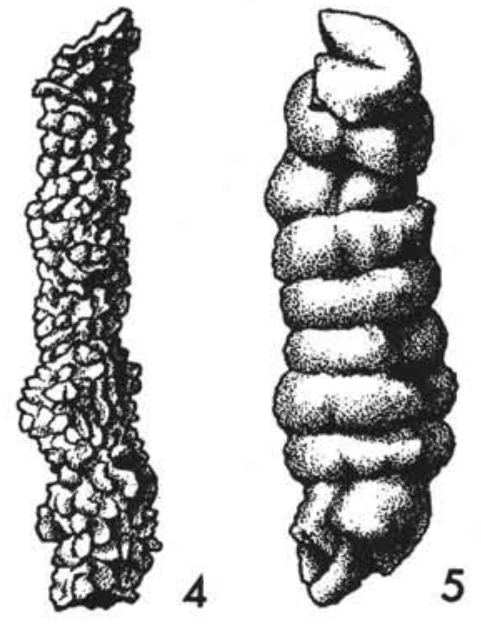
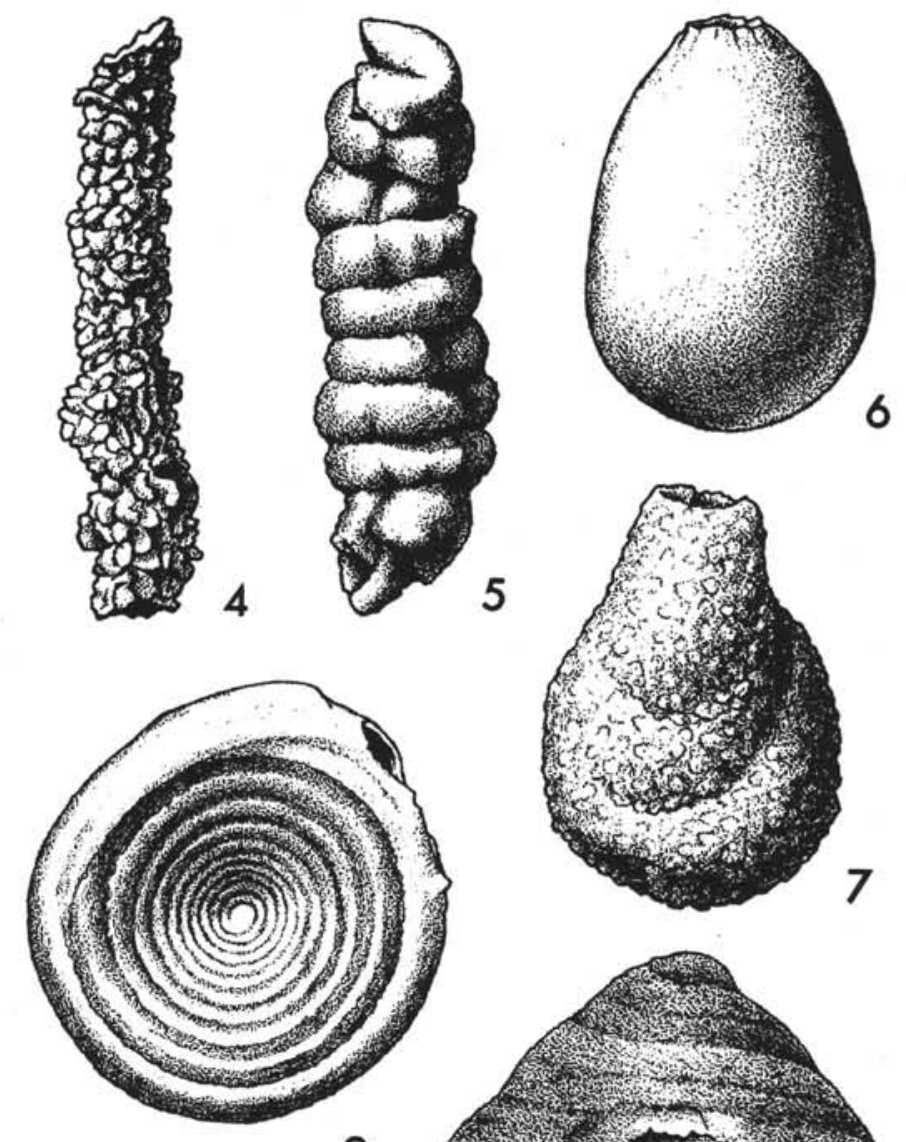

9

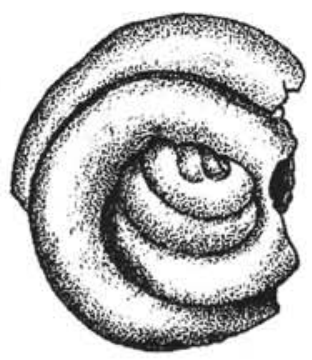

14
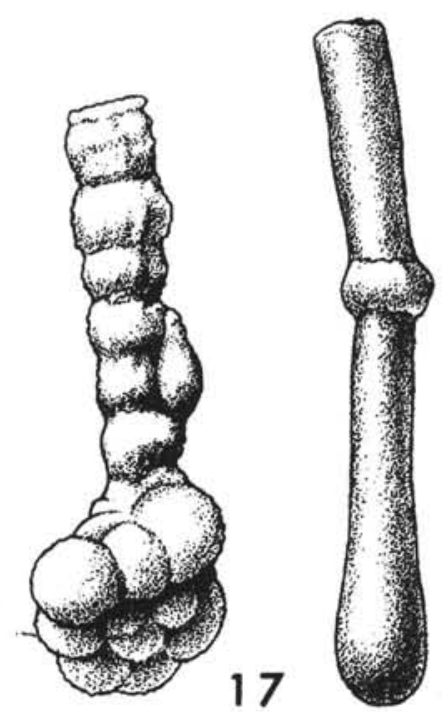

18
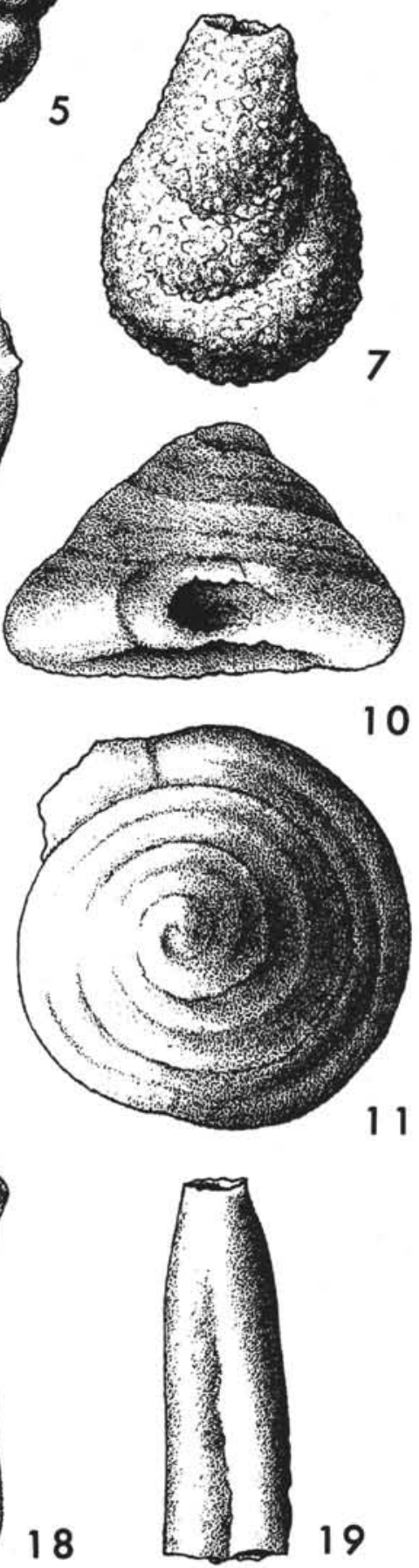
PLATE 2

(All specimens from Site 283)

Figure 1 Hormosina ovulum (Grzybowski) Sample 17, CC: $\times 120$.

Figure 2 Hormosina ovulum (Grzybowski) Sample 16, CC: $\times 120$.

Figure $3 \quad$ Reophax duplex (Grzybowski) Sample 17-1, $36 \mathrm{~cm}: \times 80$.

Figure 4 Rzehakina epigona (Rzehak) Sample 14, CC: $\times 60$.

Figure 5 Rzehakina epigona (Rzehak) Sample 14, CC: $\times 60$.

Figures 6, 7 Haplophragmoides kirki (Wickenden) Sample 15, CC: $\times 120$.

Figures 8, 9 Haplophragmoides suborbicularis (Grzybowski) Sample 16, CC: $\times 80$.

Figures 10, 11 Haplophragmoides walteri (Grzybowski) Sample 17, CC: $\times 80$.

Figure 12 Recurvoides deflexiformis (Noth) Sample 17, CC: $\times 120$.

Figure 13 Trochamminoides irregularis (White) Sample 17, CC: $\times 60$.

Figure 14 Trochamminoides proteus (Karrer) Sample 17-2, $10 \mathrm{~cm}: \times 40$.

Figures 15, 16 Cyclammina elegans (Cushman and Jarvis) Sample 17, CC: $\times 60$.

Figure 17 Ammomarginulina stephensoni (Cushman) Sample $15-1,86 \mathrm{~cm}: \times 40$. 
PLATE 2
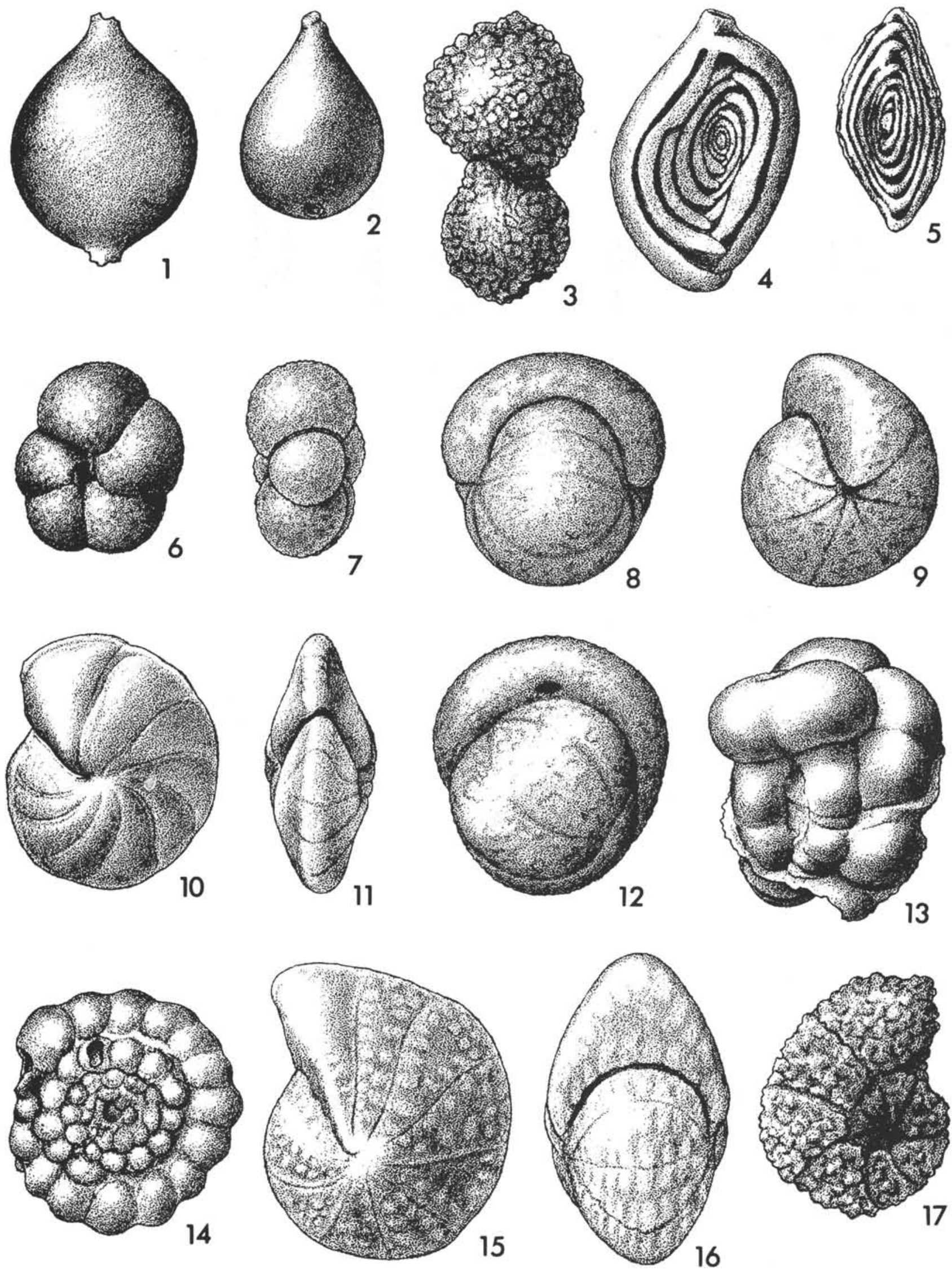


\section{PLATE 3}

(All specimens from Site 283)

Figure $1 \quad$ Bolivinopsis spectabilis (Grzybowski) Sample 17, CC: $\times 120$.

Figure 2 Bolivinopsis spectablis (Grzybowski) Sample 17, CC: $\times 90$.

Figure 3 Bolivinopsis spectablis (Grzybowski) Sample 17, CC: $\times 90$.

Figure $4 \quad$ Textularia cf. plummerae (Lalicker) Sample 16, CC: $\times 60$.

Figures 5, 6 Conotrochammina whangaia (Finlay) Sample 16-3, $17 \mathrm{~cm}: \times 60$.

Figures 7-9 Trochamminia altiformis (Cushman and Renz) Sample 17-1, $36 \mathrm{~cm}: \times 60$.

Figure $10 \quad$ Gaudryina whangaia (Finlay) Sample 12, CC: $\times 120$.

Figure $11 \quad$ Eggerella $\mathrm{sp.}$

Sample 17, CC: $\times 120$.

Figure 12 Karreriella conversa (Grzybowski) Sample 17, CC: $\times 120$.

Figure $13 \quad$ Marssonella oxycona (Reuss) Sample 12, CC: $\times 60$. 
PLATE 3
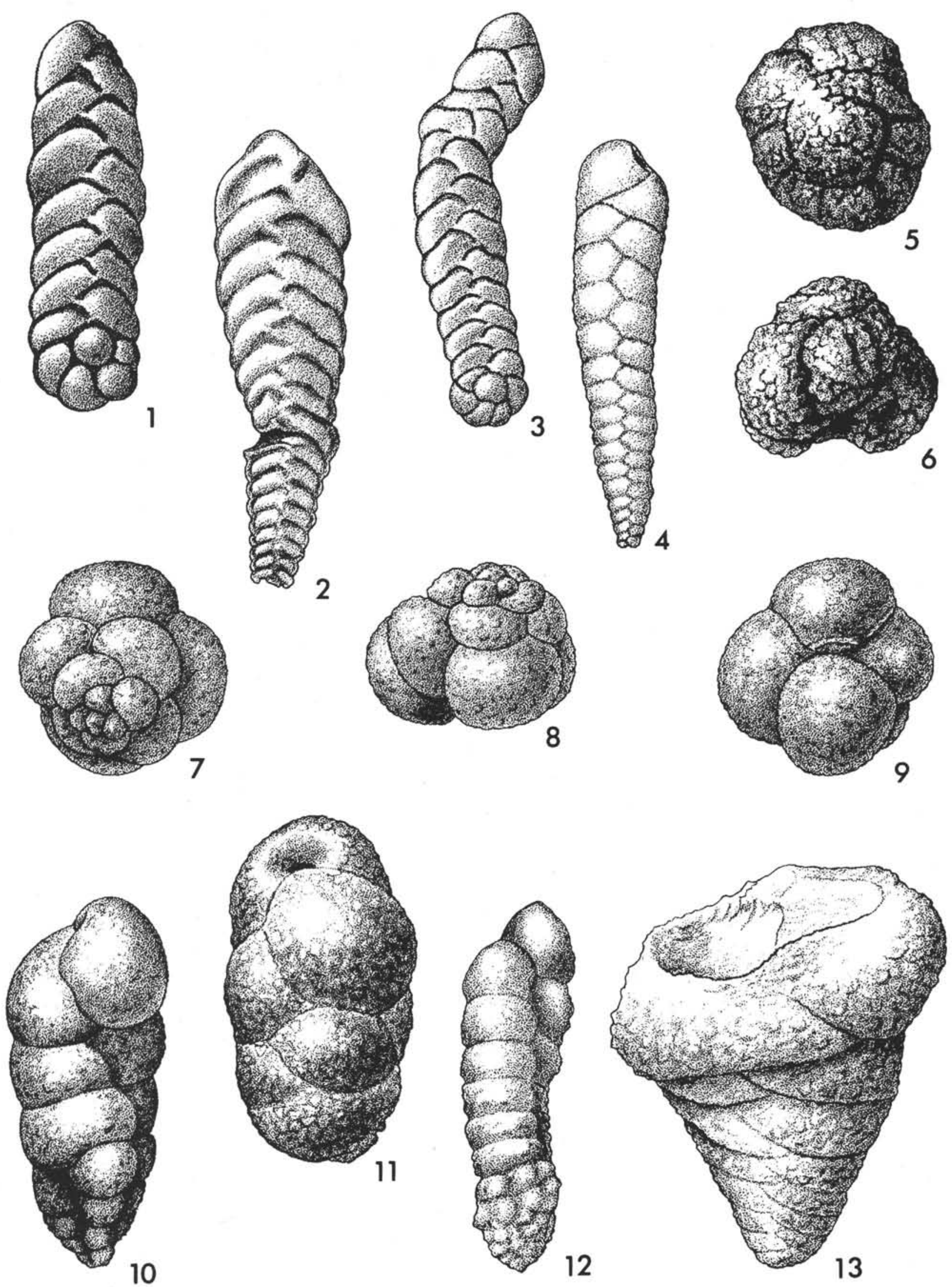